\title{
Applying Collaborative Learning for Enhancing the Teaching-Learning Process in Online Learning through Social Media
}

\author{
https://doi.org/10.3991/ijet.v16i16.23207 \\ Muralidhar $\operatorname{Kurni}^{1}{ }^{(凶)}$, K. Saritha ${ }^{2}$ \\ ${ }^{1}$ GITAM (Deemed to be University), Hyderabad, India \\ ${ }^{2}$ S.V. Degree \& P.G. College, Ananthapuramu, India \\ muralidhar.kurni@gmail.com
}

\begin{abstract}
The education system has experienced a significant paradigm change in the present pandemic situation. Traditional teaching methods, used as a marvel, will no longer function in the current situation. This shifting paradigm has affected higher education greatly, primarily because of the rapid movement from conventional approaches to advanced and creative online learning strategies. Collaborative learning is one of the most common ways of working and responding to current needs. This study deals with the influence of STAD, which is one of the collaborative learning techniques. In this research, WhatsApp, a typical social media app, is used to form groups of learners. This experiment's results demonstrate how improved learning can be achieved when collaborative learning is well used.
\end{abstract}

Keywords-higher education, collaborative learning, engineering education, online learning, active learning, social media, teaching-learning, STAD

\section{Introduction}

The containment steps of self-isolation, social distancing, and self-quarantine came with the coronavirus pandemic's advent. Therefore, many academic institutions implemented stringent lockdown measures to shut up schools and called for all students to remain at home until the epidemic was controlled. Although this meant a significant break in academic schools' academic year, this meant a considerable learning gap. However, several schools have taken appropriate measures to ensure that the learning continues at home throughout the lockdown. In addition, many institutions are using the idea of virtual classrooms and online learning through the introduction of web-based teaching and learning platforms.

Using technology for engagement is now a strategic priority for almost all institutions. In addition, all educators recognized the value of technology for communication with learners, parents, and colleagues.

Collaborative learning can improve soft skills such as decision-making, flexibility, and problem-solving $[1,2]$. In a collaborative learning approach, learners make indi- 
vidual progress in collaboration with others, collaborating towards a common goal [3]. Students are accountable to one another and, with proper guidance, can selfmanage. Students learn to understand better and anticipate variation, identify it in themselves and others, and use it to their benefit. It so good because students perform better in groups rather than in isolation, like in lockdown. Well-planned teamwork encourages all students to understand and respect the importance of their efforts. It emboldens them with the confidence to teach and learn from others - not just their peers but also their instructors.

Due to the pandemic, universities and colleges can only perform activities online with students [4]. The present study has been conducted in the Anantha Lakshmi Institute of Technology and Sciences, Ananthapuram, located in Andhra Pradesh, Southern India. "Design patterns" is the subject of this study and is an indispensable course for the Bachelor of Computer Science and Engineering program students. In this study, STAD (Student Teams Achievement Division developed by Slavin and his colleagues [5]) was used to teach the topic "Catalog of Design Patterns." STAD is one of the kinds of collaborative learning projects. The groups are created in this study through the WhatsApp Social Media App. The positive application of this methodology in this course has been shown by the quantitative and qualitative outcomes of this activity. The rest of the paper will address the conception and reflection of STAD activities for this course in depth. The document is organized as follows. Section two provides a basic introduction to collaborative learning, and section 3 describes the methodology adopted for STAD activity. Section 4 presents the results obtained by carrying out this activity, including some recommendations, and finally, section 5 concludes the work with plans.

\section{Collaborative learning}

The educational method of using groups to improve learning through working together is collaborative learning. The concept of collaborative learning is about learning in communities organized to achieve such educational objectives. Groups are small and not usually more than five participants, and they are designed to achieve a good learning result, which can be seen by gaining information and skills and performing a specific task. The students were praised for collaborative learning, enabling them to participate in discussions, assume responsibility, and become critical thinkers $[6,7]$. In elementary and secondary education, the primary domain of collaborative learning applications appears to be mature research bases. Nevertheless, wellestablished concepts apply equally, particularly in the case of engineering, to tertiary education.

It is arguable that "the advances in technology and changes in the organizational infrastructure put an increased emphasis on teamwork within the workforce. Workers need to be able to think creatively, solve problems, and make decisions as a team" [6]. Interestingly speaking, that is exactly how engineers work. In engineering practice, the notion of cooperation is inextricably rooted. Generally speaking, the engineers do not work in isolation. It is inconceivable to believe that a highly complex engineering 
project can be conceived and developed by an engineer in isolation, be it a rapid transport system or satellite communications. Collaborative learning is thus the best and most appropriate method to prepare students in engineering for the challenges ahead.

There seem to be a host of opinions about what collaborative learning is all about. These range from small-group learning [8] to learning inside and outside the classroom, the limits of local teaching and learning, and learning from a distance, where computer and IT are progressively becoming more and more important [9, 10]. For this article's purpose, the authors take the concept of collaborative learning to promote deep learning in a small team setting where the individual team members work selflessly to contribute to achieving the best learning results for the team.

\section{$3 \quad$ Methodology}

The STAD (Student Teams-Achievement Division) activity was chosen to implement Collaborating activity for the course Design Patterns for 6th Sem, B.Tech (Computer Science \& Engineering). Table 1 provides the Details of the Collaborative Learning activity conducted. The chosen topic to teach through collaborative activity is Catalog of Design Patterns. The objectives of the activity are:

- Students would be able to understand design patterns and the object-oriented principles behind them.

- Understand the context to apply the patterns.

Table 1. Details of Collaborative Learning activity conducted

\begin{tabular}{|l|l|}
\hline \multicolumn{1}{|c|}{ Activity } & \multicolumn{1}{c|}{ Student-Team-Achievement-Divisions (STAD) } \\
\hline Subject Name & Design Patterns for 6th Sem, B.Tech (CSE) \\
\hline The topic of the Subject & Catalog of Design Patterns \\
\hline Number of Class Sessions (Online-due to & Three \\
COVID 19 Lockdown) & 1. Presentation of Lesson and Team Formation \\
& 2. Team discussion and Test \\
& 3. Discussion of test answers and results \\
\hline Class strength & 40 \\
\hline Number of groups & 8, each group consists of five students \\
\hline
\end{tabular}

Two weeks after the start of the lockdown, the activity was carried out. The classes consist of four lecture hours a week and four hours of laboratory in two hours per week which deal concurrently with various topics.

\subsection{Participants}

This study's participants were 40 belonging to the sixth semester from the Undergraduate Bachelor of Technology program, Computer Science \& Engineering department. 


\subsection{Study design}

Team formation plays a vital role in Collaborative learning. Several approaches can be used: typically, homogeneous and heterogeneous.

Homogeneous teams provide equal access to participate, less chance of exclusion, more shared experiences in common, and avoid misunderstandings, thereby speed up the completion of tasks. In addition, heterogeneous teams can create more robust dynamics within a group; the group's formation can include organic production or roles and greater creativity and processing of information.

The following methods in team forming can be used.

- forming teams randomly by the instructor (heterogeneous)

- forming teams purposefully by the instructor (homogeneous)

- students forming teams on their own (homogeneous/heterogeneous)

In this study, the students are grouped into 8 groups of 5 students in each group, heterogeneously grouped by the instructor. Table 2 shows the procedure followed for establishing heterogeneous groups.

Table 2. Heterogeneous Team Formation Strategy

\begin{tabular}{|c|c|c|c|c|}
\hline Gro & r 2 & Member 3 & roup Men & Meml \\
\hline & & & . & er \\
\hline $\begin{array}{l}\text { First Internals are } \\
\text { more than } 90 \text { per- } \\
\text { cent; Practical } \\
\text { assignments } \\
\text { submitted and } \\
\text { completed on time. }\end{array}$ & $\begin{array}{c}\text { First Internals } \\
\text { Marks was } 75 \text { to } 89 \\
\text { percent; Practical } \\
\text { assignments } \\
\text { were submitted and } \\
\text { completed on time. }\end{array}$ & \begin{tabular}{|c|} 
First Internals \\
marks were 60 to 74 \\
percent; Practical \\
assignments \\
were submitted and \\
completed on time.
\end{tabular} & $\begin{array}{c}\text { First internals are } \\
\text { less than } 60 \text { percent; } \\
\text { Practical } \\
\text { assignments } \\
\text { submitted and } \\
\text { completed on time. }\end{array}$ & $\begin{array}{c}\text { First Internals are } \\
\text { less than } 40 \text { percent; } \\
\text { Practical assign- } \\
\text { ments } \\
\text { submitted and } \\
\text { completed on time. }\end{array}$ \\
\hline
\end{tabular}

The groups are created via social media in this study. Social media and its different instruments have now become an essential part of the students' everyday lives. These tools were typically used to share information and to communicate with others socially. These tools can also be used to share, promote and create online work. These resources are also supposed to undertake a wide variety of collective learning activities $[11,12]$. Higher education levels recently witness such learning resources as students speak, exchange information, and interact with other people through various social media tools. Students will have access to learning materials using these tools [13]. Here WhatsApp is used to form groups. WhatsApp was preferred here as the social media platform to create groups due to its wide range of social features like communicating, file sharing, etc.

\subsection{Procedure}

The overview of the STAD activity was given before the start of STAD in the online class. It told them how to do the STAD activity and how it would be evaluated. 


\section{Before starting the activity}

- defined the learning objectives

- provided required skills that are needed for success in the task in prior

- in each group, students are assigned particular roles

\section{Steps taken during the activity}

The general steps taken during the activity are:

- monitored the work of each group and evaluated group and individual performance

- identified and suggested the potential improvements for each group and individual

- assessed by group and individual

- Encouraged the group members to assess and reflect on their contributions periodically by self-evaluations.

- Provided opportunity to the groups and individuals to reevaluate and revise their strategies and approaches.

The specific steps taken during the activity are:

- Keep the discussion going between the team members: The material was supplied to all the students for discussion. Students are informed to go through the material thoroughly and instructed to call the instructor if they have any doubts. While the discussion was going on, the instructor monitored the students.

- Motivate non-participating members: During the discussion session, if it observed that some students are not participating actively, the instructor explained the importance of individual participation to the team and motivated the participants, and explained the importance of the session and any doubts in the material.

- Open a deadlock: After some time in the discussion session, if it identified no progress in some groups and found it difficult to proceed, the instructor explained the discussion topic by providing some examples or through diagrammatic explanations.

- To prevent collaboration from moving away from goals: The instructors monitored the teams and asked them a few basic questions about the topic to keep their collaboration from wandering away from objectives. This was done to find out whether the goal set for the task was being discussed.

\section{$4 \quad$ Results and discussion}

Table 3 shows the team-wise scores at the end of the activity.

All the teams' median score is 47 . Given the teams' heterogeneity, preferably, all the teams had a score equivalent to the median one. This isn't happening, however. The reasons for some teams scoring more than and less than the median score can be found in Table 4. 
Table 3. The team-wise score of STAD activity

\begin{tabular}{|c|c|c|c|c|}
\hline Teams & $\begin{array}{c}\text { Number of students } \\
\text { participated }\end{array}$ & $\begin{array}{c}\text { Maximum } \\
\text { Number of Marks }\end{array}$ & Marks Scored & $\begin{array}{c}\text { Total } \\
\text { Percentage }\end{array}$ \\
\hline Team-1 & 4 & 20 & 10 & 50 \\
\hline Team-2 & 3 & 20 & 15 & 75 \\
\hline Team-3 & 3 & 15 & 4 & 27 \\
\hline Team-4 & 5 & 25 & 11 & 44 \\
\hline Team-5 & 4 & 20 & 8 & 40 \\
\hline Team-6 & 3 & 15 & 4 & 27 \\
\hline Team-7 & 5 & 25 & 15 & 60 \\
\hline Team-8 & 3 & 15 & 8 & 53 \\
\hline
\end{tabular}

Table 4. Reasons for specific teams that score more than and less than the median score

\begin{tabular}{|c|c|}
\hline $\begin{array}{c}\text { Team } \\
\text { Number }\end{array}$ & Reasons \\
\hline \multicolumn{2}{|r|}{ Reasons for scoring less than the median score } \\
\hline Team-3 & $\begin{array}{l}\text { This team score was } 27 \% \text {. The team had only three students, one of whom showed no interest } \\
\text { in attending. He told the teacher that it was not their internal evaluation marks, so he was not } \\
\text { interested in taking the activity seriously. There was interest from another team student, but he } \\
\text { was a low performer; he wanted support from a good performing student. However, the team } \\
\text { score was low because the good-performing student did not belong to this team. }\end{array}$ \\
\hline Team-6 & $\begin{array}{l}\text { This team score was } 27 \% \text {. This group had one good performer and two low performers in } \\
\text { combination. Only a good-performing student achieved the score in that team, but the low- } \\
\text { performing student achieved zero marks. Therefore, the team score went down from the medi- } \\
\text { an. }\end{array}$ \\
\hline Team-5 & $\begin{array}{l}\text { This team score was } 40 \% \text {. One student in this team was a good and very active performer, and } \\
\text { he showed a strong interest in sharing his experience with others. Thus, good teamwork and } \\
\text { learning between the two took place, and the team functioned well. }\end{array}$ \\
\hline Team-4 & $\begin{array}{l}\text { This team score was } 44 \% \text {. Two students in this team are good performers, have performed well, } \\
\text { and have been very successful, showing an interest in sharing their experiences with other } \\
\text { people. Therefore, the team members had strong teamwork and learning, and the team per- } \\
\text { formed well. }\end{array}$ \\
\hline \multicolumn{2}{|r|}{ Reason for scoring greater than or equal to the median score } \\
\hline Team-1 & $\begin{array}{l}\text { This team score was } 50 \% \text {. Two students in this team were good performers, they are excellent } \\
\text { and very active, and they were keen to share their experience with others. Therefore, the team } \\
\text { members coordinated and learned well and worked well. }\end{array}$ \\
\hline Team-8 & $\begin{array}{l}\text { This team score was } 50 \% \text {. Two students are good performers, very involved in this team, and } \\
\text { have shown great interest in information sharing with other students. Therefore, the team } \\
\text { members coordinated, and learning happened well, and the team performed well. }\end{array}$ \\
\hline Team-7 & $\begin{array}{l}\text { This team score was } 60 \% \text {. Two students in this team are good performers and have shown a } \\
\text { keen interest in sharing their skills. Therefore, the team members had strong coordination and } \\
\text { learning, and the team performed well. }\end{array}$ \\
\hline Team-2 & $\begin{array}{l}\text { This team score was } 75 \% \text {. All students within this team are good performers and, therefore very } \\
\text { successful, and display a strong desire to share their experience with others. Therefore, the team } \\
\text { members coordinated well with each other, and the team worked well. }\end{array}$ \\
\hline
\end{tabular}

As the results clearly show, the teams with the best scores were right up there because of their collaborative group work. The teams performing below the median 
score did have some brilliant individual performers, but they could not gel well as a team. Hence, relatively low scores. By considering the above results, the following are the experiences gained through the collaborative activity conducted.

Positive Experiences of the attempt:

- Superior think-tank growth

- Creates an active, participatory, and exploratory learning atmosphere

- Students discuss alternative solutions to problems in a healthy environment

- Addresses student learning gaps

- The virtual grouping environment is similar to actual social and employment environments

Negative experiences of the attempt:

- Comprehensive review of the program to take into account a rise in group work

- Revision of the assignment time

- Adapting to evolving roles that involve increasing students' learning responsibilities

\section{Conclusion}

Implementing the practice described above demonstrates the value of such collaborative work by reflecting on collective learning. If students are split into teams and have to do something, they usually do their best and strive and get the job done, as is evident in the above experiment, considering the team climate's competitive nature. However, while the general inclination is to believe that team building is a very trivial step, it is not the case. These teams must be developed with a great deal of consideration, and heterogeneous teams should be created. If team training is not taken very care of and goes wrong, the entire operation risks not meeting standards. A large amount of time needs to be carefully invested in organizing teams during collaborative learning. In reality, it is not simple. If they do, collaborative learning serves as a paradigm change for most students by moving away from quick and wise active learning approaches and sharing their ideas. This leads inevitably to team success. As this is a competing group mission, most of the groups appear to be very active, and the groups aim to assist one another in achieving their team goals. While the collaborative learning exercise outcomes are present, teachers must use them in other lessons by finding specific steps to improvise further.

\section{Acknowledgment}

This research was made possible by the great support and coordination extended by the Management, Principal, and the Faculty of Computer Science \& Engineering, Anantha Lakshmi Institute of Technology and Sciences, Ananthapuram, Andhra Pradesh, India. 


\section{$7 \quad$ References}

[1] Olga V. Sumtsova, et al. (2018). Collaborative Learning at Engineering Universities: Benefits and Challenges. International Journal of Emerging Technologies in Learning, 13 (1), 160-177.

[2] Wang., C. \& Huang. L. (2021). A Systematic Review of Serious Games for Collaborative Learning: Theoretical Framework, Game Mechanic and Efficiency Assessment. International Journal of Emerging Technologies in Learning, 16 (6), 88-105. https://doi.org/ $\underline{10.3991 / i j e t . v 16 i 06.18495}$

[3] Wahyuningtyas, N. \& Idris, I. Increasing Geographic Literacy through the Development of Computer Supported Collaborative Learning. International Journal of Emerging Technologies in Learning, 15 (7), 74-85. https://doi.org/10.3991/ijet.v15i07.13255

[4] Sobaih, A. E. E., Hasanein, A. M., \& Abu Elnasr, A. E. (2020). Responses to COVID-19 in Higher Education: Social Media Usage for Sustaining Formal Academic Communication in Developing Countries. Sustainability, 12 (16), 1-18. https://doi.org/10.3390 /su12166520

[5] Jamaludin, M., \& Mokhtar, M. F. (2018). Students Team Achievement Division. International Journal of Academic Research in Business and Social Sciences, 8(2), 570-577. https://doi.org/10.6007/ijarbss/v8-i2/3966

[6] Gokhale, A.A. (1995). Collaborative Learning Enhances Critical Thinking, Journal of Technology Education, 7 (1). https://doi.org/10.21061/jte.v7i1.a.2

[7] Totten, S., Sills, T., Digby, A. \& Russ, P. (1991). Cooperative Learning: a Guide to Research. New York: Garland.

[8] Panitz, T. (1996). A Definition of Collaborative vs Cooperative Learning. DeLiberations. http://www.city.londonmet.ac.uk/deliberations/collab.learning/panitz2.html

[9] Purvis, M.A., Savarimuthu, B.T.R. \& Purvis, M.K. (2006). Architecture for active and collaborative learning in a distributed classroom environment. Advanced Technology for Learning, 3 (4), 225-232. https://doi.org/10.2316/journal.208.2006.4.208-0893

[10] Clark, S. \& Maher, M.L. (2006). Collaborative learning in a 3-D virtual place: investigating the role of place in a virtual learning environment. Advanced Technology for Learning, 3 (4), 250-254. https://doi.org/10.2316/journal.208.2006.4.208-0896

[11] Liao, Y.-W. et al. (2015). Exploring the antecedents of collaborative learning performance over social networking sites in a ubiquitous learning context. Computers in Human Behavior, 43, 313-323. https://doi.org/10.1016/j.chb.2014.10.028

[12] Ali, M. et al. (2015). Evaluating students information sharing behavior through social media: A pilot study. Australian Journal of Basic and Applied Sciences, 9 (19), 94-100.

[13] Al-Ammary, J. H. et al. (2014). The acceptance of social networking as a learning tools at University of Bahrain. International Journal of Information and Education Technology, 4 (2), 208-214. https://doi.org/10.7763/ijiet.2014.v4.400

\section{Authors}

Mr. Muralidhar Kurni is an Independent Consultant for Pedagogy Refinement, EduRefine, India. He is currently working as an Assistant Professor in the Department of Computer Science, School of Science, GITAM (Deemed to be University), Hyderabad, India. He is an IUCEE \& IGIP certified International Engineering Educator \& researcher. He has several scholarly publications to his credit. He has been a reviewer 
for various International Conferences \& Journals, including SCIE \& Scopus indexed Journals. His research interests include Mobile Ad Hoc Networks, Cloud Computing, Ad Hoc Mobile Cloud Computing, Learning Analytics, Learning Strategies, Digital Pedagogy, Design Thinking, Pedagogy refinement \& Engineering Education Research.

Dr. K. Saritha is currently working as Principal, S.V. Degree \& P.G. College, Anantapur, Andhra Pradesh. She has received Ph.D. in Computer Science from Sri Padmavati Mahila Visvavidyalayam (Women's University), Tirupati, Andhra Pradesh, India. She has $20+$ years of teaching experience. She has presented 15 papers at various national \& international conferences and journals. Her research interests are Data Mining, Blockchain, Cloud Computing, Machine Learning and Engineering education research.

Article submitted 2021-04-10. Resubmitted 2021-05-16. Final acceptance 2021-05-17. Final version published as submitted by the authors. 